\title{
The Influence of Transformational Leadership on the Quality of Early Children Education Institutions
}

\author{
Isrowiyah $^{1,2, *}$ \\ ${ }^{1}$ Educational Administration Department, School of \\ Postgraduate Studies, ${ }^{2}$ Preschool Mutiara Insani \\ ${ }^{1}$ Universitas Pendidikan Indonesia \\ Bandung, Indonesia \\ *isrowiyah11@upi.edu
}

\author{
Munir \\ Faculty of Math and Science \\ Universitas Pendidikan Indonesia \\ Bandung Indonesia
}

\begin{abstract}
This study aims to determine the relationship between transformational leadership and the quality of early childhood education institutions. The method used is quantitative with regression techniques on 100 respondents' parents. The data collection used a Likert scale questionnaire for the satisfaction of the students' parents towards school leaders. Questionnaire respondents were selected with the parents of Preschool Mutiara Insani students in Purwakarta district in the 2019-2020 school year consisting of 16 respondents, Play Group 39 respondents and 45 Kindergarten respondents. The results showed that there was a positive influence on the quality of the institution. The conclusion of this study indicates that transformational leadership applied to early childhood education institutions can improve the quality of the institution.
\end{abstract}

Keywords-early childhood education, institutional quality, transformational leadership

\section{INTRODUCTION}

School is an educational institution whose job is to provide education in accordance with policies or regulations that have been established by the government. No matter how good the policies that have been set by the government, the success of implementation really depends on the seriousness of the school in implementing it, and the seriousness that will be realized cannot be separated from the role of leadership. And leadership ethics in Islamic leadership is a responsibility where leadership is an attempt to use a type of influence not coercion for people to achieve the goals of the organization. The achievement of educational goals is highly dependent on the skills and leadership policies of the principal who is one of the educational leaders. Because the principal is a professional official in the school organization who is in charge of managing all organizational resources and working with teachers, parents in educating students to achieve quality education goals.

Our society today still considers the principal of early childhood education institutions to be considered unimportant, they assume that the principal of early childhood education is only a symbol. Because the leaders/principals of Paud are mostly institutional owners and do not have a background in the world of leadership so that many young people in Indonesia do not develop optimally, institutions only survive bankruptcy and cannot compete in the current digital era [1]. On the other hand, the leadership of early childhood education institutions is very important, considering that the leadership of an educational institution, from an early age to high school, determines the quality and quality of an institution.

\section{A. Transformational Leadership}

The Transformatioanal leadership style is able to bring about fundamental changes, such as changes in the values, goals and needs of subordinates. Which has an impact on the emergence of commitment. because the fulfillment of higher needs [2].

In quality management, there is a known approach to quality leadership, namely transformational leadership according to Gaspert. This leadership model is in accordance with the demands of quality management, because in its implementation it requires joint responsibility and empowerment, this is especially true in the transformational leadership model. In transformational leadership, the leader will try to change the entire organization and transform the organization towards a view of what the organization should do and how the organization should work towards the predetermined quality goals [3].

\section{B. Quality of the Quality Institute}

With regard to products and services, that quality and customer satisfaction are the same based on the education system, the meaning of quality is the whole education system, starting from planning, educational processes, evaluation and educational outcomes [4]

According to Crosby, quality management is to adhere to zero defects, namely there are 14 steps, one of which is Quality Measurement, which is that measurement of quality is very important, so it requires various techniques and appropriate measurement methods through monitoring and evaluation [2]. 


\section{Institute for Early Childhood Education}

According Regulation of the minister of education and culture number 81 of 2013 Program Early Childhood Education is an education program aimed at children from birth up to the age of six years are accomplished by providing stimulation of education to help the growth and development of the physical and spiritual so that children have the readiness to enter further education. Early Childhood Education, hereinafter abbreviated as PAUD, is a coaching effort aimed at children from birth to 6 (six) years of age which is carried out through providing educational stimuli to assist physical and spiritual growth and development so that children have readiness to enter further education [5].

The function of leaders in institutions from early to middle age is the same, namely to lead and manage the educational unit they lead.

Based on research highlighting transformational leadership styles' positive impact on teacher commitment, performance, job satisfaction, and other areas that help facilitate overall school success, and based on its established positive correlations to employee performance, motivation, and job satisfaction in business organizations, Bernard Bass's 1985 transformational leaders exhibit the following transformational leadership behaviors in their daily interactions with the staff or subordinates: idealized influence, inspirational motivation, individualized consideration, and intellectual stimulation [6].

The function of leaders in institutions from early to middle age is the same, namely to lead and manage the educational unit they lead. One of the functions of educational leadership is as a manager which consists of planning, organizing, leading, and controlling the efforts of organizational members, as well as optimally empowering available resources in order to achieve the stated goals of educational institutions. Leadership as a manager must be able to perform management functions to realize the goals of educational institutions in achieving quality education [7].

\section{RESEARCH METHODS}

\section{A. Research Objectives}

One aspect that can be used to determine whether or not the quality of an educational institution (school) is the school's relationship with parents, which can be seen through the involvement of parents in children's education at school. The involvement of parents in early childhood education institutions is very important considering the perceived impact of the success of a school on parents because early childhood cannot provide an assessment or statement that the school where they learn is good or bad so that parents know and feel it. To find out the quality of schools, especially in Mutiara Insani Preschool, at the end of each academic year, parents were given a survey questionnaire to find out how parents were satisfied with the school, especially the principal.

\section{B. Data Collection Techniques}

The data were collected using a survey questionnaire on the satisfaction of the parents of students towards school leaders, especially for parents of students whose children will graduate. This research method was conducted in July with the aim of knowing how the results of parental satisfaction with the leadership of the principal. Questionnaire respondents were selected with the parents of Preschool Mutiara Insani students in Purwakarta district in the 2019-2020 school year consisting of 16 respondents, Play Group 39 respondents and 45 Kindergarten respondents. A survey questionnaire was given during the distribution of the second semester report cards and each parent answered 10 statements and the questionnaire was collected again that day. Survey of Parental Satisfaction Survey of Mutiara Insani Preschool Leadership, example:

\section{QUESTIONNAIRE}

Parents' Satisfaction with Mutiara Insani Preschool Leadership for the 2019/2020 Academic Year

Name of Parent

Name of Student :

Class

Fill in this questionnaire based on the statements (table 1) in the column below by putting a tick (V) based on your opinions and experiences during the 2019 - 2020 school year at Mutiara Insani Preschool.

$\begin{array}{ll}\text { TS: } & \text { Disagree } \\ \text { R: } & \text { Doubt - Doubt } \\ \text { S: } & \text { Agree } \\ \text { SS: } & \text { Strongly Agree }\end{array}$

TABLE I. STATEMENTS

\begin{tabular}{|c|c|c|c|c|c|}
\hline \multirow[t]{2}{*}{ NO } & \multirow[t]{2}{*}{ REPRESENTATION } & \multicolumn{4}{|c|}{ OPTIONS } \\
\hline & & SS & $S$ & $R$ & $T S$ \\
\hline 1. & $\begin{array}{l}\text { Principal convey Vision - Mission School } \\
\text { clearly. }\end{array}$ & & & & \\
\hline 2. & $\begin{array}{l}\text { The Principal delivers School programs and } \\
\text { activities before the start of the new school } \\
\text { year. }\end{array}$ & & & & \\
\hline 3. & $\begin{array}{l}\text { The Principal conveys the responsibility for } \\
\text { school activities for } 2 \text { semesters }\end{array}$ & & & & \\
\hline 4. & $\begin{array}{l}\text { The principal is flexible and friendly to } \\
\text { students, teachers and parents }\end{array}$ & & & & \\
\hline
\end{tabular}


Table 1. Cont.

\begin{tabular}{|l|l|l|l|l|l|}
\hline 5. & $\begin{array}{l}\text { Principals in making decisions act quickly, } \\
\text { decisively and benefit all parties }\end{array}$ & & & & \\
\hline 6. & $\begin{array}{l}\text { The school principal accommodates } \\
\text { suggestions and aspirations of the school } \\
\text { community }\end{array}$ & & & \\
\hline 7. & $\begin{array}{l}\text { The principal works well with the Committee } \\
\text { in advancing the school. }\end{array}$ & & & \\
\hline 8. & $\begin{array}{l}\text { The school principal nurtures and becomes a } \\
\text { role model for school residents }\end{array}$ & & & \\
\hline 9. & $\begin{array}{l}\text { The principal is transparent in conveying } \\
\text { school finances }\end{array}$ & & & & \\
\hline 10. & $\begin{array}{l}\text { School programs and activities are achieved } \\
\text { according to targets }\end{array}$ & & & \\
\hline
\end{tabular}

\section{RESULTS AND DISCUSSION}

Internal Quality Assurance is quality assurance carried out by educational institutions in a manner determined by the implementing educational institution. The parameters and measuring the results are determined by the educational institution according to its vision and mission. By carrying out internal quality is called periodic self-evaluation. Selfevaluation is intended to strive for continuous quality improvement [8].

In improving the internal quality of the institution, based on the results of a survey questionnaire from respondents at Mutiara Insani preschool, data is obtained as in the figure 1 below:

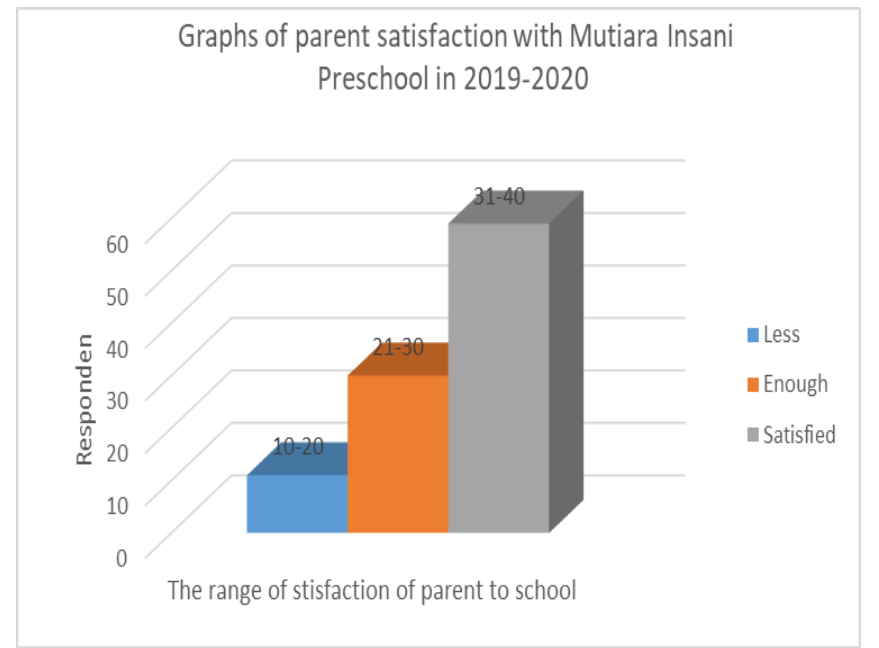

Fig. 1. Graph of parent satisfaction with Mutiara Insani Preschool in 20192020.

\section{Information}

Parents Satisfaction Range with School

$$
\begin{array}{ll}
\text { - Less } & : \text { Score } 10-20 \\
\text { - Fair } & : \text { Score } 21-30 \\
\text { - Satisfied } & : \text { Score } 31-40
\end{array}
$$

Number of Respondents

$\begin{array}{ll}\text { - Less } & : 11 \text { Respondents } \\ \text { - Enough } & : 30 \text { Respondents } \\ \text { - Satisfied } & : 59 \text { Respondents }\end{array}$

In the graph above it can be seen that the parents who were less satisfied were 11 respondents, 30 respondents were quite satisfied and 59 respondents were satisfied. It can be concluded that 89 respondents are in the quite satisfied range and are already satisfied with the Mutiara Insani Preschool institution in the 2019-2020 school year. This research will be continued in the following year until the parents who are less satisfied become zero as in the sense that quality is the highest service is zero deppect.

\section{CONCLUSION}

Leadership is the core in the organization plays an important role in improving the quality of the institution because the leader is the main person who determines the black and white of the organization. Transformational leaders influence based on the leader's ability to inspire others through words, attitudes, conversations, insights and initiatives. With a transformational leadership approach, the principal is based on future aspirations so that the institution is quality and can compete. It is the leader's duty to transform organizational values and have diagnostic expertise and always take the time to solve problems from various aspects, one of which is to improve the quality of the institution.

\section{REFERENCES}

[1] R. Diadha, Involvement of Parents in Early Childhood Education in Kindergarten - Kindergarten, 2017.

[2] A.K. Engkoswara and A. Komariah, Administrasi pendidikan. Bandung: Alfabeta, 2010.

[3] E. Herawan, "Leadership Quality of School Principals in Improving the Quality of Education," 2018.

[4] F. Ismail, "Improving the Quality of Islamic Education Institutions," 2017.

[5] Regulation of the Minister of Education and Culture Number 81 of 2013 concerning the Establishment of Early Childhood Education.

[6] M. Anderson, "Transformational leadership in education: A review of existing literature,” International Social Science Review, vol. 93, no. 1, p. 4, 2017.

[7] Rohmat, "Educational Leadership," 2006.

[8] D. Nurdin and B. Ismaya, Administrasi dan Manajemen Sumber Daya Pendidikan. Bandung: Refika Aditama, 2018. 